\title{
DEVELOPMENT AND SILK PRODUCTION BY SILKWORM LARVAE AFTER TOPICAL APPLICATION OF METHOPRENE
}

\author{
José Ednilson Miranda ${ }^{1 *}$; Sérgio Antonio de Bortoli ${ }^{1}$ Roque Takahashi² \\ ${ }^{1}$ Depto. de Fitossanidade - UNESP/FCAV, Via de Acesso Prof. Paulo Donato Castellane, s/n. - CEP: 14884-900 - \\ Jaboticabal, SP. \\ 'Depto. de Zootecnia - UNESP/FCAV. \\ ${ }^{*}$ Corresponding author <joseemiranda@ig.com.br>
}

\begin{abstract}
Juvenile hormone analogues have been tested as insect growth regulators in silkworm (Bombyx mori), seeking an increment of silk production. These chemical products, when applied in small or moderate rates, promote the extension of the last larval instar. To understand the physiologic consequences on silk production by the silkworm strain $\mathrm{C} 115 \times \mathrm{N} 108$, the application of methoprene, a juvenile hormone analogue, was performed to evaluate its effects on larval development and silk production. Methoprene was topically applied $48 \mathrm{~h}$ after the fourth larval ecdysis, on the dorsal integument of the 2 nd thoracic segment of the insects, at seven rates between 0 and $20 \mathrm{ng}$ a.i. Methoprene influenced positively the duration of the fifth instar and the weight gain of the insects. The application of $1 \mathrm{ng}$ methoprene resulted in the heaviest silkglands, cocoons, shell cocoons and pupae weights. Comparatively to the control, the increment on silk production (approximately $24 \%$ ) by the use of $1 \mathrm{ng}$ methoprene was more accentuated than the corresponding negative effects on the cocooning rate (approximately $12 \%$ ).
\end{abstract}

Key words: Bombyx mori, JHA, sericulture, juvenile hormone

\section{DESENVOLVIMENTO E PRODUÇÃO DE SEDA POR LAGARTAS DO BICHO-DA-SEDA APÓS APLICAÇÃO TÓPICA DE METHOPRENE}

\begin{abstract}
RESUMO: Análogos do hormônio juvenil têm sido testados como reguladores de crescimento de insetos em Bombyx mori, com vistas ao incremento da produção de seda. Estes produtos químicos, quando aplicados em pequenas ou moderadas doses, promovem prolongamento do último ínstar larval. O presente estudo visou o entendimento das conseqüências fisiológicas na produção do bicho-da-seda da linhagem C115xN108 face a aplicação de methoprene, um análogo do hormônio juvenil, através da determinação de seus efeitos sobre o desenvolvimento larval e a produção de seda. Methoprene foi aplicado, por via tópica, 48 horas após a quarta ecdise larval, sobre o tegumento dorsal do segundo segmento torácico dos insetos, em sete doses entre 0 e 20 ng de i.a. Methoprene influenciou positivamente a duração do ínstar e o ganho de peso dos insetos. A aplicação de $1 \mathrm{ng}$ de methoprene resultou nos pesos mais elevados de glândulas sericígenas $(1,89 \mathrm{~g})$, casulos cheios $(2,36 \mathrm{~g})$, casulos vazios $(0,62 \mathrm{~g})$ e pupa $(1,74 \mathrm{~g})$. Comparativamente ao controle, 0 incremento na produção de seda pelo uso de $1 \mathrm{ng}$ de methoprene (aproximadamente $24 \%$ ) foi mais acentuado que os correspondentes efeitos negativos na taxa de encasulamento (aproximadamente 12\%).

Palavras-chave: Bombyx mori, AHJ, sericicultura, hormônio juvenil
\end{abstract}

\section{INTRODUCTION}

The ecdysis process in insects is regulated by two hormones, one produced by neurosecretory cells in the brain (prothoracicotropic hormone) and another by the prothoracic glands (ecdysone). In addition the juvenile hormone, secreted by the corpora allata, when in high concentration, assures that the larvae retain their larval characteristics, preventing metamorphosis into an adult. Juvenile hormone analogues have been tested in Bombyx mori as insect growth regulators in order to increase silk production (Akai et al., 1984, 1988; Kajiura et al., 1987; Kajiura \& Yamashita, 1989; Chowdhary et al., 1990; Cappellozza et al., 1997). These chemical products, when applied in diminute and appropriate rates, promote the extension of the larval period, when the insect feeds.
The first studies with juvenile hormone analogues in $B$. mori were accomplished through topical applications on the insect (Akai et al., 1971, 1973; Murakoshi et al., 1972). Later, researchers looked for the practical application of these hormones in the sericulture, through spraying or immersion of the leaves into the products (Akai et al., 1981, 1984; Nihmura et al., 1972; Gaaboub et al., 1985; Sarangi, 1988).

Akai et al. (1985) reported $30 \%$ increase on silk ratio over the control, after the application of the C18JH synthetic hormone. Chang et al. (1972) mentioned a $20 \%$ increase in cocoon weight when the silkworm larvae were treated with a juvenile hormone analogue. Chowdhary et al. (1986) noticed a $21 \%$ increment of silk production by the use of the SJ-42-F juvenile hormone. 
The physiological effects on insects caused by the application of juvenile hormone analogues vary according to the product, rate (Cappellozza et al., 1997; Chowdhary et al., 1990), insect strain (Gaaboub et al., 1985; Sarangi, 1988), application method and time (Kotikal \& Devaiah, 1986). The present study sought to determine the effects of the topical application of rates of methoprene on the larval development and silk production of C115xN108 silkworm larvae.

\section{MATERIAL AND METHODS}

Bombyx mori larvae (C115xN108 strain) were reared in laboratory conditions in the Faculdade de Ciências Agrárias e Veterinárias - Universidade Estadual Paulista, Campus of Jaboticabal, SP, Brazil, under controlled temperature $\left(26 \pm 2^{\circ} \mathrm{C}\right)$, relative humidity $(70 \pm 10 \%)$ and photophase (14 hours). For larvae feeding, mulberry leaves (FM Shima-Miura cultivar) were supplied ad libitum, five times a day. Forty eight hours after the beginning of the fifth instar, the silkworm larvae were topically treated with methoprene at the rates of $0,0.1,0.5,1,5,10$ and 20 ng a.i., diluted in $5 \mathrm{~mL}$ ethanol solvent. Larvae of the control (that received $0 \mathrm{ng}$ ) were only treated with the solvent. The applications were on the larval thoracic tergum, ideally on the second thoracical by using 100 $\mathrm{mL}$ micro-syringe controlled by a Burkard 900-x microapplicator.
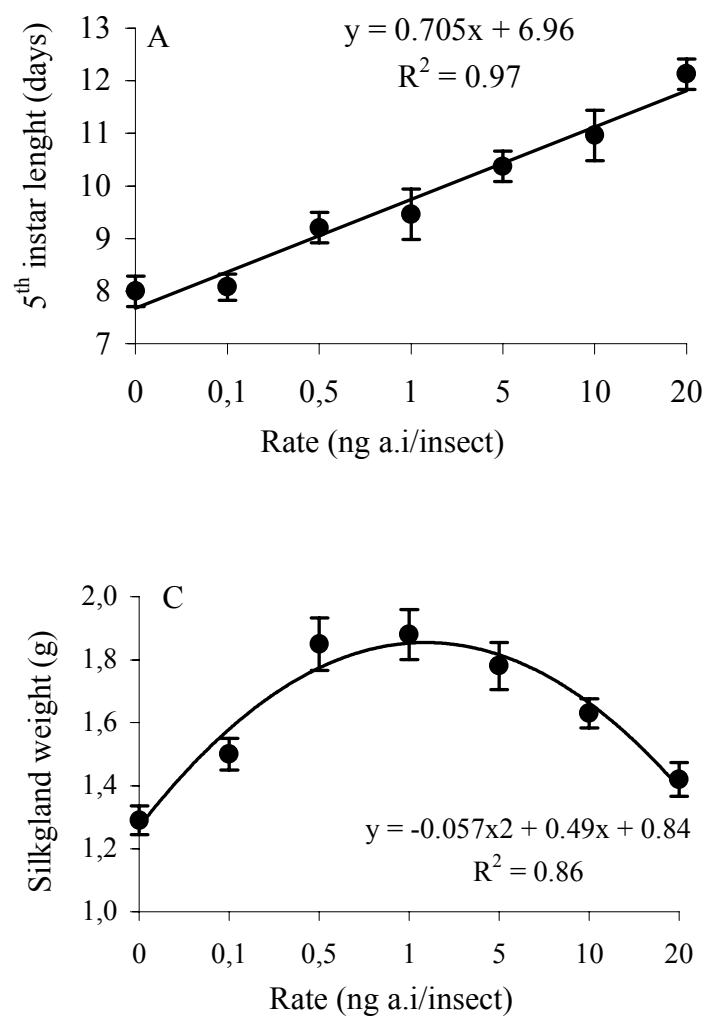

In order to evaluate the relationships between rates and the larval and cocoon characteristics, linear and non-linear regression analyses were performed. A completely randomized design was used, with seven treatments (rates) and four replicates. Data were analyzed using the GLM procedure (SAS System).

\section{RESULTS AND DISCUSSION}

The application of methoprene extended the fifth larval instar. The extension was highly related to the rate, i. e., increases in the rates incurred in linear increases of the larval period of the treated larvae (Figure 1a). Rates between 0.1 and $20 \mathrm{ng}$ methoprene extended the B. mori fifth instar from 8 to 12 days, approximately. High rates induce the formation of "permanent larvae", which do not accomplish the pupal metamorphosis (Akai et al., 1988; Subba Rao et al., 1988). Kajiura et al. (1987) observed a 28-day length on the fifth instar of insects that received $50 \mathrm{mg}$ methoprene 48 hours after the fourth ecdysis. With rates between 0 and $20 \mathrm{ng}$ of methoprene, no permanent larvae were observed.

The weight gain of the methoprene-treated larvae increased linearly as the rates increased, varying from 4.65 to $5.70 \mathrm{~g}$ (Figure 1b). The increment in the larval weight gain after methoprene application was probably a direct physiologic effect, considering that the extended feeding period seems to be the predominant factor for the largest weight gain.
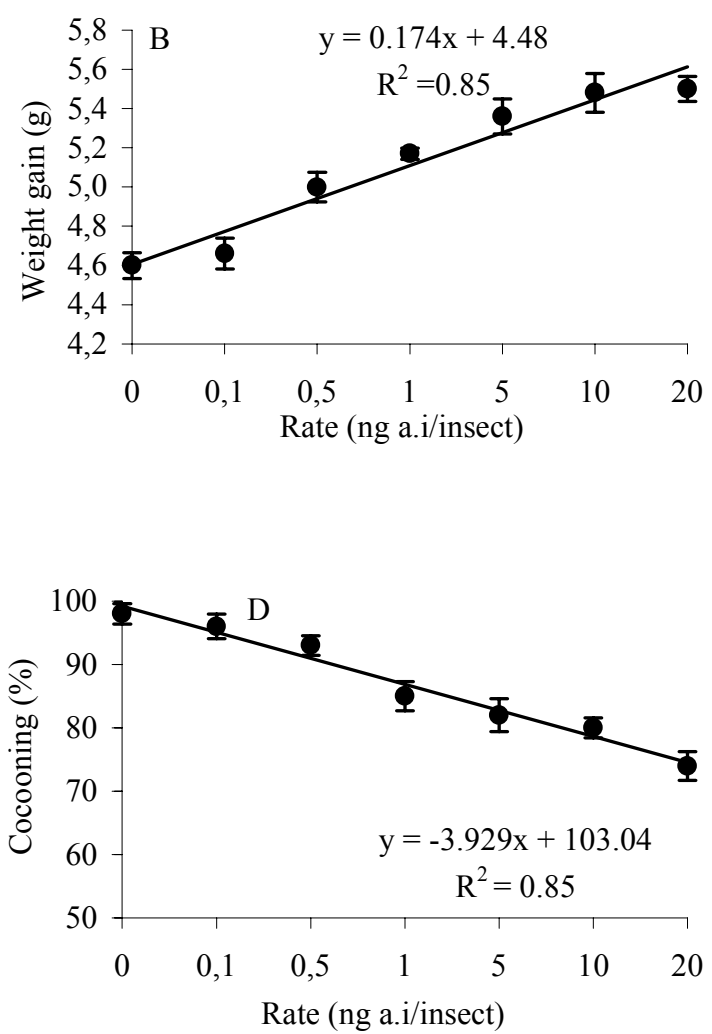

Figure 1 - Effects of the topical application of methoprene on the development of Bombyx Mori larvae. A) fifth instar length; B) weight gain; C) silkgland weight; D) cocooning rate. 
Methoprene promoted increase in the weight of B. mori silkglands with applications of rates up to $1 \mathrm{ng}$; higher rates tended to cause a decline in the silkgland weight (Figure 1c). The effect of the juvenile hormone analogue on insects happens, through the influence on their morphogenesis, i. e., causing an increment in weight gain, a portion of this biomass weight gain is directed to the growth of silkglands (Novák, 1966). In fact, a positive correlation was observed between weight gain and the weight of the silkglands $(r=0.99 ; P<0.05)$. The results are consistent with those of Kajiura \& Yamashita (1989), who noticed the elongation of the feeding period, due to the topical application of methoprene, was reflected mainly in the growth of the silkgland. According to those authors, the growth of the silkglands continues until the synthesis of silk proteins in the cells stops. Consequently, juvenile hormone analogues seem to act maintaining the activity of the silkglands during the extended period during the end of the fifth instar.

The higher the rate of methoprene applied on insects, the higher the decrease on the cocooning rate, characterized by, a linear decrease pattern (Figure 1d). The rates ranged from $99 \%$ cocooning for non-treated larvae to $75.5 \%$ cocooning for larvae receiving maximum dose 1). Since methoprene did not prevent the insect metamorphosis, the cocooning decline can be related to metabolic disturbances in the insects. Several metabolic processes are influenced by the juvenile hormone
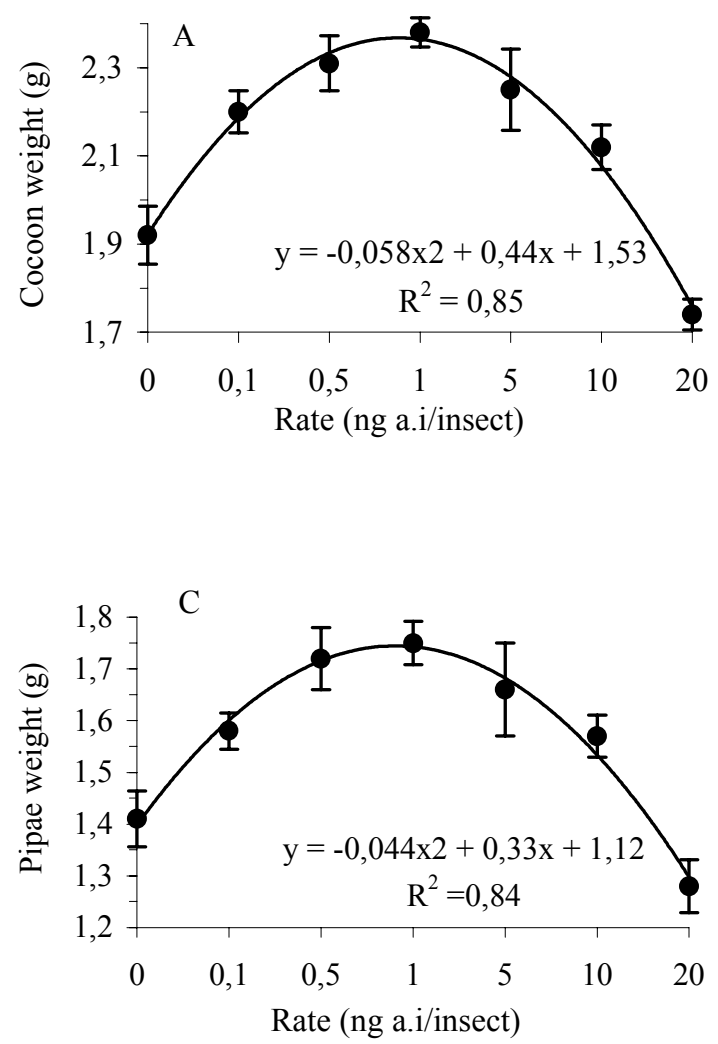

besides metamorphosis inhibition, such as histogenesis alterations protein, synthesis oxygen consumption and nitrogen, purine and enzyme metabolism of (Novák, 1966). In fact, the interactions between the juvenile hormone and the insect body metabolism are quite complex and require further studies.

The regression curves for cocoon, cocoon shell and pupae weights showed similar patterns. Increases in these characteristics occurred on larvae treated with up to $1 \mathrm{ng}$ methoprene; above this rate, a decline was verified (Figures 2a, 2b and 2c). These curves are explained in that larvae receiving high rates of juvenile hormone analogue have the feeding rhythm and the consumption rate reduced during the extended feeding period (Leonardi et al., 1996). The maintenance cost of this extended period might have contributed for the decrease of the pupa body weight. The decrease in silkgland weight of larvae treated with high rates (Figure 1c) possibly led to the correspondent decline in the shell cocoon weight. Both factors probably influenced cocoon weight. Correlation analyses showed high positive correlations, with Pearson's coefficients of $0.93(P<0.05)$, $0.99(P<0.05)$ and $0.97(P<0.05)$ among cocoon weight/ shell cocoon weight, cocoon weight/pupa weight, and shell cocoon weight/pupa weight, respectively. The organic compounds accumulated by the insects in the larval stage were proportionally distributed for both silk production and the pupa body constitution. These results
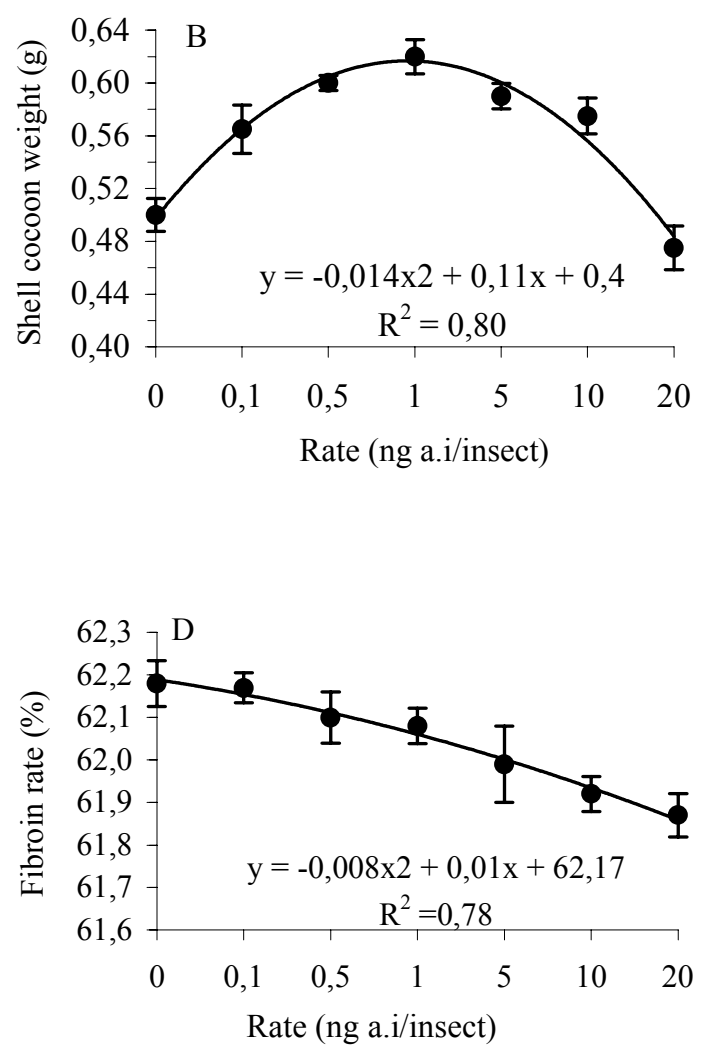

Figure 2 - Effects of the topical application of methoprene on the silk production by Bombyx mori. A) cocoon weight; B) shell cocoon weight; C) pupae weight; D) fibroin rate. 
agree partially with those of Chowdhary et al. (1990), who observed that the application of methoprene resulted in significant increase in larval and pupal weights, without increase, however, in shell cocoon weight, i. e., the volume of food ingested by the insect during the extended feeding period was transformed in bady material.

The fibroin rate from the cocoons of methoprenetreated larvae tended to decrease as the rate increased, indicating the negative influence of the product on the protein synthesis (Figure 2d). These results confirm those obtained by Sarangi (1988), who verified decreases in the fibroin rate when methoprene was applied in chronic rates on silkworms. The fibroin is synthesized in the granular endoplasmic reticulum of cells from the posterior portion of the silkglands and transported until the Golgi complexes of these cells, where it is condensed as fibroin globules. Liquid fibroin is then released in the lumen to be carried to the spinnerets, which are labial glands that secrete the silk at the moment of the cocoon formation (Akai et al., 1973). High rates of juvenile hormone analogues inhibit the intracellular transport of fibroin (Akai \& Kiguchi, 1980). Thereby, in spite of the increased fibroin synthesis, silk secretion is hindered above a certain rate of hormone, affecting cocoon weight, as verified in the present study with rates between 1 and $20 \mathrm{ng}$ methoprene, or even causing the formation of "permanent larvae", which present large amount of silk in the silkglands, but are not able to secrete them to produce the cocoon (Akai et al., 1981).

\section{CONCLUSIONS}

The application of $1 \mathrm{ng}$ methoprene to fifth instar larvae of $B$. mori increases their development and silk production, compensating the corresponding reduction of cocooning rate. However, field studies using practical methods of application of the product on the insects, are needed to confirm the benefit of such technique in sericulture.

\section{ACKNOWLEDGEMENTS}

To FAPESP, for scholarship (Proc. n. 97/136596 ) and for the financial support of this research.

\section{REFERENCES}

AKAI, H.; KIGUCHI, K.; MORI, K. Increased accumulation of silk protein accompanies $\mathrm{KJH}$-induced prolongation of larval life in Bombyx mori $\mathrm{L}$. Applied Entomology and Zoology, v.6, p.218-220, 1971.

AKAI, H.; KIGUCHI, K.; MORI, K. The influence of juvenile hormone on the growth and metamorphosis of Bombyx larvae. Bulletin of the Sericultural Experiment Station of Japan, v.25, p.287-305, 1973.
AKAI, H.; KIGUCHI, K. Ultrastructural changes of the posterior silkgland cells from the allata-ectomized $4^{\text {th }}$-instar larvae of Bombyx mori. Bulletin of the Sericultural Experiment Station of Japan, v.28, p.1-14, 1980.

AKAI, H.; KIGUCHI, K.; KOBARI, Y.; SHIBUKAWA, A. Practical utilization of juvenoids for increasing silk production. Scientific Papers of the Institute of Organic Physical Chemistry, v.22, p.781-792, 1981

AKAI, H.; KIMURA, K.; KIUCHI, M.; SHIBUKAWA, A. Effects of anti-juvenoid treatment on cocoon and cocoon filaments in Bombyx mori. Journal of Sericultural Science of Japan, v.53, p.545-546, 1984.

AKAI, H.; KIMURA, K.; KIGUCHI, K.; SHIBUKAWA, A. Increase of silk production by repeated treatment with a juvenile hormone analogue. Journal of Sericultural Science of Japan, v.54, p.297-299, 1985.

AKAI, H.; TAKABAYASHI, K.; KIUCHI, M. Induction of spinning from JH-treated larvae of Bombyx mori by ecdysteroid administration. Journal of Sericultural Science of Japan, v.57, p.341-344, 1988.

CAPPELLOZZA, L.; IANNE, P.; CAPPELLOZZA, S. Effect of body weight on effectiveness of the insect growth regulator (I.G.R.) fenoxycarb applied to the male and female silkworm (Bombyx mori) (Lepidoptera: Bombycidae). Sericologia, v.37, p.443-452, 1997

CHANG, C.F.; MURAKOSHI, S.; TAMURA, S. Giant cocoon formation in the silkworm, Bombyx mori L. topically treated with methylenedioxyphenyl derivates. Agricultural Biology and Chemistry, v.36, p.629-694, 1972.

CHOWDHARY, S.K.; SEHNAL, F.; RAJ, S.K.; RAJU, P.S.; MATHU, S. Giant cocoon formation in Bombyx mori L. topically treated with juvenile hormone SJ-42-F. Sericologia, v.26, p.455-459, 1986.

CHOWDHARI, S.K.; RAJU R.S.; OGRA, R.K. Effect of JH analogues on silkworm, Bombyx mori L., growth and development of silk gland. Sericologia, v.30, p.155-165, 1990.

GAABOUB, I.A.; EL-HELALY, M.S.; MOSTAFA, S.M. Food utilization, rate of larval growth, and fecundity of Bombyx mori L. (Lepidoptera: Bombycidae) fed mulberry leaves treated with methoprene, triprene, and diflubenzuron. Journal of Economic Entomology, v.78, p.1182-1186, 1985.

KAJIURA, Z.; KADONO-OKUDA, K.; YAMASHITA, O. Induction of dauer larvae by a juvenile hormone analogue and their response to ecdysteroids in the silkworm, Bombyx mori. Journal of Sericultural Science of Japan, v.56, p.398-406, 1987.

KAJIURA, Z.; YAMASHITA, O. Super growth of silkglands in the dauer larvae of the silkworm, Bombyx mori, induced by a juvenile hormone analogue. Journal of Sericultural Science of Japan, v.58, p.39-46, 1989.

KOTIKAL, Y.; DEVAIAH, M.C. Juvenile hormones in sericulture. Indian Silk, v.25, p.19-20, 1986.

LEONARDI, M.G ; CAPPELLOZZA, S: IANNE, P ; CAPPELLOZZA, L: PARENTI, P.; GIORDANA, B. Effects of the topical application of an insect growth regulator (fenoxycarb) on some physiological parameters in the fifth instar larvae of the silkworm Bombyx mori. Compendium of Biochemistry and Physiology, v.113B, p.361-365, 1996.

MURAKOSHI, S.; CHANG, C.F.; TAMURA, S. Increase in silk production by silkworm, Bombyx mori L. due to oral administration of juvenile hormone analogue. Agricultural Biology and Chemistry, v.36, p.695-696, 1972.

NIHMURA, M.; AOMORI, S.; MORI, K.; MATSUI, M. Utilization of synthetic compounds with $\mathrm{JH}$ activity for the silkworm rearing. Agricultural Biology and Chemistry, v.38, p.889-892, 1972.

NOVÁK, V.J.A. Insect hormones. London: Methuen, 1966. 478p.

SARANGI, S.K. Effect of juvenile hormone analogue on the silk gland of the silkworm, Bombyx mori L. Sericologia, v.28, p.553-557, 1988.

SUBBA RAO, G.; DAS, S.K.; SEN, S.K.; NANDI, S.; SOMPOMU, R. A study on the effect of a juvenile hormone analogue on the bivoltine silkworm, $B$. mori L. Sericologia, v.28, p.543-564, 1988.

WIGGLESWORTH, V.B. Physiology of insect metamorphosis. Journal of Insect Physiology, v.7, p.73, 1961.

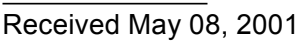

